Juliane Hennig-Breitfeld ${ }^{a, *}$, H. Tim Breitfeld ${ }^{a}$, Robert Hall ${ }^{a}$, Marcelle BouDagher-Fadel ${ }^{b}$

${ }^{a}$ SE Asia Research Group, Department of Earth Sciences, Royal Holloway University of London, Egham, TW2O $O E X, U K$

${ }^{b}$ Department of Earth Sciences, University College London, London, WC1H OBT, UK

\title{
Reply to Discussion:
}

Hennig-Breitfeld, J., H.T. Breitfeld, R. Hall, M. BouDagher-Fadel, and M. Thirlwall. 2019. A new upper Paleogene to Neogene stratigraphy for Sarawak and Labuan in northwestern Borneo:

Paleogeography of the eastern Sundaland margin. Earth-Science Reviews 190, 1-32.

We thank Peter Lunt for his comment and his recognition of the importance of our new work. We welcome the opportunity to discuss further the implications of our new field and analytical data that led us to a view of the stratigraphy of Sarawak and Labuan on land different from his. In contrast to Lunt's statements, we do not think that our stratigraphic model is in conflict with much published work. Below we provide additional information to clarify and illustrate our new interpretation of the tectono-stratigraphic evolution of northern Sarawak in contrast to that presented in his Fig. 1.

The comment illustrates the need for further research in the region. Many of the issues raised by Lunt are based not on new data, but on interpretations of literature from the 1960s, correlations from distant Sabah exposures or offshore wells, or unpublished industry reports. For example, Reinhard and Wenk (1951) are cited for identifying "the most important Tertiary orogeny of North Borneo" from an angular discordance reported in Sabah, apparently supported by unpublished comments by Bowen and Wright (1957), although in Sarawak Wolfenden (1960) commented that the "stratigraphic evidence is difficult to reconcile with the concept of an Upper Eocene orogeny that caused the entire... ...Rajang Group to be folded". However, this misses the point of our paper, which was based on our own new field observations in Sarawak and Labuan and reinterpreted stratigraphic relations there. While we agree that previous field-based studies (e.g. Kirk, 1957; Wolfenden, 1960; Liechti et al., 1960) provide valuable information, it is also important to be aware of their uncertainties and limitations. Geological concepts have changed over the years (e.g. Kirk (1957, Plate VII) illustrates ripple marked Rajang Group sandstones captioned as "deposited in shallow-water marine conditions" which are now regarded as deep marine turbidites), biostratigraphic ages and time scale markers have been revised, and mapping was largely based on field observations limited to rivers combined with interpretations based on aerial photographs, whereas nowadays high resolution radar imagery provides significantly improved insights into structural relationships, seeing through vegetation cover, and GPS devices enable more precise location of outcrops.

We presented new $\mathrm{U}-\mathrm{Pb}$ age data from igneous rocks, biostratigraphy, and sediment data (light and heavy mineral compositions, $\mathrm{U}-\mathrm{Pb}$ detrital zircon analysis) to determine maximum depositional ages and identify sediment provenance (Hennig-Breitfeld et al., 2019). We contend that the new data support major unconformities on land at c.37 Ma and c.17 Ma which are not those identified by previous workers. Our data also identify major changes in provenance in the Early Oligocene and late Early Miocene, in contrast to Lunt's claim that "widespread outcrops of Oligocene and Miocene clastic formations share a common sediment provenance". In our paper we drew upon previous literature concerning hinterland uplift and coastline reorientation, clearly important and acknowledged; in addition, we also provided new paleogeographic maps and drainage 
reconstructions based on our age dating, provenance data and stratigraphic interpretations, which are new and original findings.

Below we respond to the main points of the comment which are discussed in stratigraphic order. We have focussed on our research area and have not responded to comments about the Sabah region which is not discussed in our paper. We have taken the opportunity to update our geological map (Fig. 1), including remote sensing interpretations based on recently acquired high-resolution $(12 \mathrm{~m})$ TanDEM-X imagery (Wessel, 2016), our own field observations, and information from earlier workers (notably Kirk, 1957; Wolfenden, 1960; Liechti et al., 1960). Our geological map shows more clearly the different interpretations and locations of stratigraphic units and major unconformities (Figs. 1 and 2). We provided further details on the microfossil identifications and added two more images to our photomicrograph chart (Fig. 3) to confirm our reported ages and depositional environment interpretations. Microfossil assemblages referred to in Lunt's comment have been re-evaluated and differing results are discussed.

\section{The Bawang Member of the Belaga Formation, the Tatau Formation, and the Rajang Unconformity}

An important difference in our stratigraphy from older interpretations is the separation of the former Tatau Formation into the Bawang Member of the Belaga Formation, which is below the Rajang Unconformity, and our redefined Tatau Formation above the Rajang Unconformity subdivided into the Lower Tatau Formation (Rangsi Conglomerate) and Upper Tatau Formation. The Piring Intrusives and Arip Volcanics (Fig. 1), which are interbedded with the Bawang Member, yielded Middle to Late Eocene U-Pb zircon ages, with the youngest zircons of 37-39 $\pm 1 \mathrm{Ma}$, indicating that magmatism continued until c.37 Ma, and provides the lower age limit for our Rajang Unconformity. We also dated samples of the Arip Limestone, above and close to the Arip Volcanics, which yielded similar late Middle Eocene ages.

The term Arip Limestone is not a new term introduced by us as suggested by Lunt. It was used previously by Wong (2011) who included the limestones as a member of the former Tatau Formation and is now within our Bawang Formation. The term is sensible since the limestones are close to the Arip Volcanics (Liechti et al., 1960), in the Arip River valley (Fig. 1). Larger benthic and planktonic foraminifera analysed by Wong (2011) from samples on the south side of the Tatau High and Arip valley indicated Middle and Late Eocene ages, similar to our biostratigraphic results, and none of the assemblages were interpreted as Oligocene.

Lunt suggests the limestones in the Arip valley (i.e. our Arip Limestone) should be assigned to the Sap Marls or Penian Marl. The Sap Marl Member (Liechti et al., 1960) was named from near Tatau village northeast of the Tatau High, very far from the Arip valley and is at the base of their Tatau Formation. As we explain below, we assign the Oligocene samples on the north side of the Tatau High near the Sap River (location C on Fig. 1), to the Upper Tatau Formation. Liechti et al. (1960, page 202) described the Penian Marl Formation as a marl and shale succession and make no mention of limestones; they also observe that its stratigraphic position is very uncertain. Wolfenden (1960) reported marls in the subsurface west of the Penipah River (located in the Mukah-Balingian province east of Mukah, well to the west of the area mapped in Fig. 1) which he "tentatively referred on lithological grounds to the Tatau Formation". He stated that "previously they were referred to 
the Penian Marl Formation, and generally believed to be of Miocene age. Little is known about these rocks and further work is needed to clarify their stratigraphic position". Thus, the stratigraphic position of both the Sap Marls and Penian Marls remains uncertain and we do not agree that the Arip Limestone should be assigned to them.

Lunt claims that "none of the illustrated fossils are [...] age diagnostic even of a general Eocene age" and requested better proof in illustrations. We have therefore added two images to our planktonic photomicrograph chart (Fig. 3B, I, L). The samples studied are mainly micritic wackestone with rare recrystallized foraminifera. Planktonic foraminifera occur sporadically in the samples and are mainly small globular trochospiral, non-muricate species. Rare morozovellids are represented by Acarinina spp. with a broadly rounded or subangular periphery, but with no enlarged peripheral muricae and no muricocarinae. Acarinina spp. are typical Eocene forms and the presence of Acarinina pentacamerata (Fig. 3A) and Acarinina cf. bulbrooki (Fig. 3B) indicate a late Ypresian-Lutetian age, P8-P11, 51.0-42.3 Ma (see BouDagher-Fadel, 2015). The first appearance of trochospiral forms is in the Lutetian and is characterised by the lack of strong cancellations (e.g. Dentoglobigerina venezuelana, Fig. $3 \mathrm{C}$ ). The globular Paleogene globanomalinids with a smooth test and a slight and subangular periphery, such as Turborotalia frontosa (Fig. 3D), and the smooth hantkeninids such as Aragonella nuttalli (Fig. 3E) with high radially elongate chambers indicate a Lutetian age, P10-P11, 47.8-42.3 Ma in AL1-1 and AL1-2. Other small globular eoglobigerinids, such as Subbotina eocaenica (Fig. 3F) with cancellate pitted tests and the streptospiral porticulasphaerids, such as Globigerinatheka sp. (Fig. 3G) Globigerinatheka lutherbacheri (Fig. 3H), Globigerinatheka barri (Fig. 3I) are more common in the samples. These forms, together with the high spired, loosely coiled, streptospiral micro-perforate Guembelitrioides higginsi (Fig. 3J), indicate a late Lutetian age, P11P12a, 44.9-41.2 Ma, in AL3-2 (see BouDagher-Fadel, 2015). The common presence of the Paleogene biserial forms (e.g. Chiloguembelina sp., Fig. 3K), the globular small non-muricate globigerinids and the absence of the heavily muricate deep water Morozovella which inhabited deeper oceanic layers indicate a shallow inner neritic environment (BouDagher-Fadel, 2015). The limestones could have been deposited in such a neritic environment but could also represent material reworked into a deeper setting.

Lunt argues that these ages disagree with historical records and referred to the pelagic assemblages reported by Wolfenden (1960). Six of the 16 samples of Wolfenden (1960, his Table 10) were dated as Eocene, and are all located in the area of the Arip anticline (Fig. 1) and therefore are not in conflict with dates from our Bawang Member, including the Arip Limestone. Ten other samples were reported as Oligocene which are located north of the Kelawit Fault near Tatau village, or south of the Kelawit Fault in the Arip valley. These samples could be from formations above the Rajang Unconformity. However, two of the six Eocene samples also contained "Globigerina" cf. dissimilis (= Catapsydrax dissimilis, Fig. 3L). This form is one of only two species found in the Oligocene samples, however, it ranges from Middle Eocene to Early Miocene, P12 to N5 (see BouDagher-Fadel, 2015). Therefore, the identification as Oligocene of the ten samples is solely based on "Globigerina" cf. increbescens. Forms similar to Paragloborotalia increbescens (= "Globigerina cf. increbescens") range from Late Eocene to Early Oligocene, P15 to P20, 38.0-29.2 Ma (see Premoli Silva et al., 2003, BouDagher-Fadel, 2015). The relatively wide age range of these species thus prevents a clear assignment of age. 
Wolfenden (1960) also reported benthic foraminifera which yielded Eocene ages in all samples collected north of the Kelawit Fault on the south side of the Tatau High and south of the Kelawit Fault in the Arip valley which would be the Arip Limestone in the Bawang Member in our stratigraphy. One other sample north of the Kelawit Fault on the north side of the Tatau High near the Sap River (location C on Fig. 1) was determined as Oligocene, which supports our stratigraphic interpretation as Upper Tatau Formation. There is one location reported with Late Eocene ages from limestone lenses northeast of the Tatau High (again near location C). This location is below the Rajang Unconformity on our map (Fig. 1) - and hence an Eocene age is reasonable. The field relations are not described so the limestones could be faulted blocks from below the unconformity, or be reworked in younger sediments above the unconformity.

In the Arip valley area the key observation is that the limestones are interbedded with the folded turbidite sequences and are therefore below our Rajang Unconformity. Our new biostratigraphic ages are based on the most recent classifications, and these are late Middle Eocene. Assemblages previously considered Late Eocene could be Middle Eocene due to shifts in the correlation of the East Indian letter stages and modern geological time scales (Adams et al., 1986; BouDagher-Fadel and Banner, 1999; McGowran, 2005). However, even if a Late Eocene age is supported by future research it would not require major changes to the stratigraphy; simply extending the upper age range of the Upper Bawang Member from late Middle to Late Eocene would result in a slightly younger age for the Rajang Unconformity.

Lunt's Fig. 1 separates a Lower Tatau Formation from an Upper Tatau Formation by the Rajang Unconformity. This is not our Rajang Unconformity. Galin et al. (2017), and later Hall and Breitfeld (2017), introduced this term for an unconformity at c.40 Ma, which we now consider to be slightly younger (c.37 Ma) based on the youngest zircons in magmatic rocks within the Bawang Member. Our Rajang Unconformity (Fig. 1) is at the base of Rangsi Conglomerate north of the Kelawit Fault, and at the base of the Buan Formation south of the Kelawit Fault.

This is one of several examples where Lunt's stratigraphic positioning relies solely on old field observations made by Wolfenden (1960) and Liechti et al. (1960), and unpublished Shell reports. Liechti et al. (1960) and Wolfenden (1960) did suggest there is an un-named 800 feet thick conglomerate which marks an unconformity within their Tatau Formation. Liechti et al. (1960) showed the proposed unconformity in a cross-section (their Fig. 7) above the Arip Volcanics and its position is marked on Fig. 1. Both Liechti et al. (1960) and Wolfenden (1960) considered the conglomerates to rest unconformably on the Arip Volcanics but also observed that the unconformity has never been seen; neither do they mark the conglomerates on any of their maps.

There are several problems with this interpretation. Firstly, our field observations do not support the presence of a thick conglomerate unconformably above the Arip Volcanics within the former Tatau Formation (our Bawang Member). In the Arip valley south of the Kelawit Fault, close to the road, there is an abrupt change from the Arip Volcanics to turbidite sandstones and no possible room for 800 feet of conglomerates. The rocks in the Arip anticline dip very steeply northwards and such a thickness of conglomerates would be a prominent feature, even in an area which is thickly vegetated and difficult to access.

Furthermore, Fig. 7 in Liechti et al. (1960) shows that their interpreted unconformity does not mark an important stratigraphic change, because both below and above the unconformity are deep 
marine sediments. The conglomerate was interpreted to rest on the Arip Volcanics but it is dominated by chert and vein quartz clasts; Liechti et al. (1960) mention "some igneous fragments" and Wolfenden (1960) comments that "volcanic components are rare, indicating that the conglomerate was derived mainly from erosion of sedimentary rocks". Both authors appear to consider that the volcanics indicate terrestrial conditions, which would have been the standard view in 1960, but it is now well known that welded tuffs and lavas can be erupted in deep marine settings so there is no requirement for significant change in conditions during deposition of the former Tatau Formation (our Bawang Member). Liechti et al. (1960) commented that "the conglomerate on top of the rhyolites marks probably an unconformity..." which "...presumably resulted from the Upper Eocene folding". However, maps by Liechti et al. (1960), Wolfenden (1960), and our own (Fig. 1) show clearly that the supposed unconformity is strongly folded by the Arip anticline, with the overlying upper part of the Bawang Member, indicating that the folding post-dated the Bawang Member and pre-dated the Buan Formation. This is one reason for the positioning of our Rajang Unconformity (Fig. 1).

We have checked the locations of Wolfenden's (1960) traverses and almost all are located to the north of the Kelawit Fault and not in the Arip valley to the south of the fault. North of the Kelawit Fault there certainly are conglomerates, and we have observed them in many locations, but these are part of the Rangsi Conglomerate at the base of our Tatau Formation. Therefore, an explanation of the field observations by earlier workers is that they correctly interpreted an unconformable contact, which they did not observe, but it is between the Arip Volcanics and the Rangsi Conglomerate, and may be locally faulted (location A on Fig. 1). We have drawn the supposed unconformity of Liechti et al. (1960) as well as our Rajang Unconformity on Fig. 1 for comparison, and sketched the sedimentary and stratigraphic relations in Figure 2 at locations A to C (Fig. 1) to illustrate our interpretation. Northeast of the Tatau High (near location C on Fig. 1) we observed an almost complete sequence of Belaga Fm - Rajang Unconformity - Rangsi Conglomerate - Upper Tatau Formation - Buan Formation - Nyalau Formation. In the Arip valley to the south of the Kelawit Fault (location B on Fig. 1) the sequence is less well exposed and inferred partly from field observations and TanDEM-X imagery, but is Arip Volcanics - Arip Limestone - upper part of the Bawang Member - Rajang Unconformity - Buan Formation - Nyalau Formation.

\section{Top Crocker Unconformity (TCU) and Deep Regional Unconformity (DRU)}

Lunt states in the comment that our suggestion of much debate on the timing or even existence of regional unconformities is unfairly pessimistic. We did not intend to be pessimistic, simply realistic, as any reading of the literature shows there is much disagreement and uncertainty about naming and dating the numerous unconformities in the north Borneo region. Lunt himself correlates the Top Crocker Unconformity (TCU) with the Base Miocene/Base Meligan Unconformity (BMU), and claims that that the TCU was combined with the Deep Regional Unconformity (DRU) at c.17 Ma in our paper. Both statements are incorrect, which illustrates the point we were trying to make.

On the first point, Lunt argues that the unconformity above the Temburong Formation (base of Te5) is not late Early Miocene but rather at the Oligocene-Miocene boundary. This assumption is based on the extinction of "Globigerina" binaiensis (= Globoquadrina binaiensis), stated by Lunt to be at about 19.4 Ma, which in itself does not exclude an Early Miocene age as the Oligocene-Miocene 
boundary is now dated as $23.03 \mathrm{Ma}$ (Gradstein et al., 2012; Ogg et al., 2016). To further clarify this point, we re-evaluated the original data of Wilson and Wong (1964). Wilson and Wong (1964) dated the Temburong Formation as Oligocene-Miocene. However, the listed foraminifera are mainly Early Eocene to Middle Eocene (e.g. "Hastigerina" micra = Pseudohastigerina micra, Late Ypresian to Early Bartonian, P7 to P13, 52.3-39.2 Ma), and Late Eocene (e.g. "Globigerina" centralis = Turborotalia centralis), Late Bartonian to Priabonian, P15 to P17, 38-33.9 Ma; Hantkenina alabamensis, Late Lutetian to Priabonian, P12 to P17) (see BouDagher-Fadel, 2015). They also recorded foraminifera which are late Middle Eocene to Early Miocene (e.g. Catapsydrax dissimilis, Late Lutetian to Burdigalian, P12 to N6) or Oligocene to Earliest Miocene (e.g. "Globigerina" binaiensis = Globoquadrina binaiensis), Late Oligocene-Early Miocene, P22 to N5, 26.8-18.0 Ma). So the extinction date of the earliest Miocene recorded form is not at about 19.4 but at about 18.0 Ma (see BouDagher-Fadel, 2015). On the other hand, they record Globigerinoides trilobus which does not appear before the early Miocene N5 planktonic zone, 21.0 Ma (BouDagher-Fadel, 2015). Thus, a maximum age of c.18 Ma is consistent with the Wilson and Wong (1964) data.

A late Early Miocene maximum depositional age for the top of the Temburong Formation is further strengthened by recently analysed U-Pb zircon data of a tuffaceous sandstone that yielded a mean age of c.19.5 Ma (Breitfeld et al., 2019) with the three youngest zircons ages between $18.3 \pm 0.3$ and $18.6 \pm 0.6 \mathrm{Ma}$. Thus the TCU, which is above the Temburong Formation, must be younger than that and we conclude that c.17 Ma is the likely age of our proposed Nyalau Unconformity, not the Oligocene-Miocene boundary as shown in Lunt's Fig. 1.

On the second point, although not relevant to our paper, Levell (1987) reported an angular unconformity, the Deep Regional Unconformity (DRU), to be "closely constrained to occur within the Globorotalia peripheroacuta zone, i.e. early Middle Miocene", and showed it on chronostratigraphic diagrams to be close to the base of the Middle Miocene; the base of the Middle Miocene is now dated as $15.97 \mathrm{Ma}$. Furthermore, his Fig. 8 map shows the DRU and gives it a c.15 Ma age which was the age we gave for the unconformity. As discussed in our paper we do not interpret the conglomerate exposed on Labuan as marking the DRU. We disagree that this is a "very obvious unconformity on Labuan Island", based on our own field observations. There are similar deltaic to shallow marine sequences below and above the conglomerate, no major lithological changes, no discordance, and thus no major change in environment which would justify a major unconformity in the sequence. It should be noted that the identification and significance of the DRU has recently been challenged, and it is suggested to be more complex boundary separating sandy units of Middle to Late Miocene mini-basins from underlying mobile shales (e.g. Clark, 2017).

\section{The Nyalau Unconformity}

The Nyalau Unconformity proposed at c.17 Ma is not discussed in detail in our paper, but is considered by us to be an important boundary. Incidentally, Lunt is not correct to infer we derived the unconformity or its age from work by Simmons et al.; it is based on a major provenance change between the Nyalau Formation and the overlying Balingian, Begrih and Liang formations in the Mukah-Balingian province reported in our paper. This indicates a major change in sediment source driven by hinterland uplift and coastline reorientation. The timing of this event was narrowed down 
in our stratigraphy based on the age of the Nyalau Formation, which has been reported as Oligocene to the Early Miocene by many previous authors (e.g. Wolfenden, 1960; Liechti et al., 1960; Haile, 1962; Kho, 1968; Mat-Zin, 2000; Hutchison, 2005; Wong, 2011; Hassan et al., 2013), and the Balingian Formation which was dated as Early to Middle Miocene by Murtaza et al. (2018) based on palynology.

The Balingian Formation was initially considered to be Late Miocene based on foraminifera assemblages (Liechti et al., 1960) resulting in an estimated Early Pliocene and Late Pliocene to Pleistocene age for the overlying Begrih and Liang Formations respectively. However, recent $\mathrm{U}-\mathrm{Pb}$ dating of zircons from a tuff layer in the Liang Formation (Ramkumar et al., 2018) yielded $11.4 \pm 0.4$ to $11.8 \pm 0.8 \mathrm{Ma}$ mean ages (late Middle Miocene) which enabled more precise stratigraphic positioning for the whole Mukah-Balingian sequence and highlights the importance of absolute age dating of critical horizons.

In Lunt's Fig. 1 the Balingian Formation is shown to be early Early Miocene age and he states that "the Balingian Formation of southern Sarawak is Cycle II to ? In age", referring to an un-named onshore well and precise dating based on modern palynology. We disagree with this interpreted correlation. Although not specifically listed in the likely well description, seismic profiles clearly show an unconformity (marked as Base Cycle V) below the uppermost sequence (Y. Said, pers. comm., 2019), which is mapped as the Balingian Formation (Heng, 1992). In this case, the early Early Miocene age may be very precise, but is from rocks below the unconformity in "Cycles II and ?!" (most likely Cycle II) which we correlate with the Nyalau Formation.

To conclude, the previous literature summarised above does not support an upper limit of the Nyalau Formation at the Oligocene-Miocene boundary as shown in Lunt's Fig. 1. We have recently conducted new biostratigraphic analysis of the Nyalau Formation, Setap Shale Formation, and Subis Limestone, which indicate similar age ranges for all three formations (different to that shown in Lunt's Fig. 1) that extend into the Early Miocene until c. $17 \mathrm{Ma}$, which is further support for the upper limit for the Nyalau Formation in our stratigraphy. The proposed age is similar to that suggested by Hutchison (2005), who also identified a major change at that time, associated with coastline reorientation and uplift in Sarawak.

The comment makes several statements about a "continuous mid Early Miocene to Middle Miocene succession". This apparent continuity is unsurprising, considering that both the Nyalau and Balingian Formations consist of very similar lithologies and represent similar depositional environments. However, our study shows that they had very different sources, with implications for important changes in hinterland uplift and drainage evolution, which highlights the power of provenance tools that formed the basis for our paleogeographic reconstructions.

Much of the information in the literature is based on excellent studies by geological survey and industry geologists, carried out many years ago, and remains extremely valuable, but new methods, new data and changing interpretations can build on and change our understanding of north Borneo geology, and indeed require changes. We believe that it is crucial to carry out new research to resolve some of the uncertainties associated with older data, and to better understand this fascinating and under-studied region, and we especially encourage new field research to test our model. We certainly agree with Lunt that greater access to unpublished industry data would be of benefit to everyone working in the region. 


\section{Acknowledgement:}

We thank the TanDEM-X Science Communication Team (German Aerospace Center (DLR) e.V.) for providing the TanDEM topographic data.

\section{References:}

Adams, C.G., Butterlin, J., Samanta, B.K., 1986. Larger foraminifera and events at the Eocene/Oligocene boundary in the Indo-West Pacific region. Developments in Palaeontology and Stratigraphy 9, Elsevier, 237-252.

BouDagher-Fadel, M. K., 2015. Biostratigraphic and Geological Significance of Planktonic Foraminifera (Updated 2nd Edition). London, UK, UCL Press, pp. 306.

BouDagher-Fadel, M.K., Banner, F.T., 1999. Revision of the stratigraphic significance of the Oligocene-Miocene "Letter-Stages". Revue de Micropaléontologie 42, 93-97.

Breitfeld, H.T., Macpherson, C., Hall, R., Thirlwall, M., Hennig-Breitfeld, J., 2019. Adakites without a slab: Remelting of hydrous basalt in the crust and shallow mantle of Borneo to produce the Miocene Sintang Suite and Bau Suite magmatism of West Sarawak, Lithos 344-345, 100-121.

Bowen, J. M., Wright, J. A., 1957. Geology of the Crocker Range and adjoining areas. Sabah Shell (unpublished).

Clark, J., 2017. Neogene Tectonics of Northern Borneo: A Simple Model to Explain Complex Structures within Miocene-recent Deltaic-Deepwater Sediments, Proceedings of the 2017 Asia Petroleum Geoscience Conference \& Exhibition (APGCE), 88-91.

Galin, T., Breitfeld, H.T., Hall, R., Sevastjanova, I., 2017. Provenance of the Cretaceous-Eocene Rajang Group submarine fan, Sarawak, Malaysia from light and heavy mineral assemblages and U-Pb zircon geochronology. Gondwana Research 51, 209-233.

Gradstein, F. M., Ogg, J. G., Schmitz, M. D., Ogg, G. M., 2012. The Geologic Time Scale 2012. Elsevier, pp. 1,144 .

Haile, N.S., 1962. The geology and mineral resources of the Suai-Baram area, north Sarawak. Geological Survey Department British Territories in Borneo, Memoir 13, 176 pp.

Hall, R., Breitfeld, H.T., 2017. Nature and demise of the Proto-South China Sea. Geological Society of Malaysia, Bulletin 63, 61-76.

Hassan, M.H.A., Johnson, H.D., Allison, P.A., Abdullah, W.H., 2013. Sedimentology and stratigraphic development of the upper Nyalau Formation (Early Miocene), Sarawak, Malaysia: a mixed wave-and tide-influenced coastal system. Journal of Asian Earth Sciences 76, 301-311.

Heng, Y.E., 1992. Geological Map of Sarawak, 1:500,000. Geological Survey of Malaysia.

Hennig-Breitfeld, J., Breitfeld, H.T., Hall, R., BouDagher-Fadel, M., Thirlwall, M., 2019. A new upper Paleogene to Neogene stratigraphy for Sarawak and Labuan in northwestern Borneo:

Paleogeography of the eastern Sundaland margin, Earth-Science Reviews 190, 1-32.

Hutchison, C.S., 2005. Geology of North-West Borneo. Elsevier, Amsterdam, 421 pp. 
Kho, C.H., 1968. Bintulu area, Central Sarawak, East Malaysia. Geological Survey Borneo Region, Malaysia, $83 \mathrm{pp}$.

Levell, B.K., 1987. The Nature and Significance of Regional Unconformities in the HydrocarbonBearing Neogene Sequence Offshore West Sabah. Geological Society of Malaysia Bulletin 21, 55-90.

Liechti, P., Roe, F.W., Haile, N.S., 1960. The Geology of Sarawak, Brunei and the western part of North Borneo 3, 360 pp.

Mat-Zin, I.C., 2000. Stratigraphic Position of Rangsi Conglomerate in Sarawak. Platform 1, 25-31.

McGowran, B., 2005. Biostratigraphy: Microfossils and Geological Time. Cambridge University Press, $459 \mathrm{pp}$.

Murtaza, M., Rahman, A.H.A., Sum, C.W., Konjing, Z., 2018. Facies associations, depositional environments and stratigraphic framework of the Early Miocene-Pleistocene successions of the Mukah-Balingian Area, Sarawak, Malaysia. Journal of Asian Earth Sciences 152, 23-38.

Ogg, J.G., Ogg, G.M., Gradstein, F.M., 2016. A concise geological time scale, Elsevier, 240pp.

Premoli Silva, I., Rettori, R., Verga, D. 2003. Practical manual of Paleocene and Eocene planktonic foraminifera, ed: Rettori, D., Verga, D., Perugia, Italy, 1-152p.

Ramkumar, M., Santosh, M., Nagarajan, R., Li, S.S., Mathew, M., Menier, D., Siddiqui, N., Rai, J., Sharma, A., Farroqui, S., 2018. Late Middle Miocene volcanism in Northwest Borneo, Southeast Asia: Implications for tectonics, paleoclimate and stratigraphic marker. Palaeogeography, Palaeoclimatology, Palaeoecology 490, 141-162.

Reinhard, M., Wenk, E., 1951. Geology of the colony of North Borneo. Geological Survey Department of the British Territories in Borneo (Bulletin), 1, 160 pp.

Wessel, B., 2016. TanDEM-X Ground Segment - DEM Products Specification Document. EOC, DLR, Oberpfaffenhofen, Germany, Public Document TD-GS-PS-0021, Issue 3.2, 2016. [Online]. Available: https://tandemx-science.dlr.de/

Wilson, R.A.M., Wong, N.P.Y., 1964. The geology and mineral resources of the Labuan and Padas Valley area, Sabah, Malaysia 17, $150 \mathrm{pp}$.

Wilson, M.E.J., Wah, E.C.E., Dorobek, S., Lunt, P., 2013. Onshore to offshore trends in carbonate sequence development, diagenesis and reservoir quality across a land-attached shelf in SE Asia. Marine and Petroleum Geology 45, 349-376.

Wolfenden, E.B., 1960. The Geology and Mineral Resources of the Lower Rajang Valley and adjoining areas, Sarawak. British Territories Borneo Region Geological Survey Department, Memoir 11, 167 pp.

Wong, Y.L., 2011. Stratigraphy of the Ransi Member of the Middle Eocene to Oligocene Tatau Formation in the Tatau-Bintulu area, Sarawak, East Malaysia. MSc Thesis, University of Malaya, Kuala Lumpur, $256 \mathrm{pp}$. 


\section{Captions:}

Fig. 1: Geological maps of the Tatau region modified from Wolfenden (1960), Liechti et al. (1960) and Heng (1992) on the basis of our field observations and remote sensing interpretations using the topographic TanDEM-X basemap from TerraSAR-X @ DLR 2019.

Fig. 2: Cartoons showing interpreted stratigraphic relations at locations A, B and C on Fig.1.

Fig. 3: Selected photomicrographs of planktonic foraminifera. Scale bar $=0.25 \mathrm{~mm}$. A - Acarinina pentacamerata (Subbotina), AL3-3. B - Acarinina cf. bulbrooki (Bolli), AL2-2. C - Dentoglobigerina venezuelana (Hedberg), AL2-3. D - Turborotalia frontosa (Subbotina), AL1-2. E - Aragonella nuttalli Toumarkine, AL1-1. F - Subbotina eocaenica (Terquem), AL1-2. G - Globigerinatheka sp., AL2-2. H Globigerinatheka lutherbacheri Bolli, AL3-2. I - Globigerinatheka barri (Brönnimann), AL2-2. J Guembelitrioides higginsi (Bolli), AL2-1. K - Chiloguembelina sp., AL3-4. L. Catapsydrax dissimilis (Cushman and Bermudez). AL2-2. 


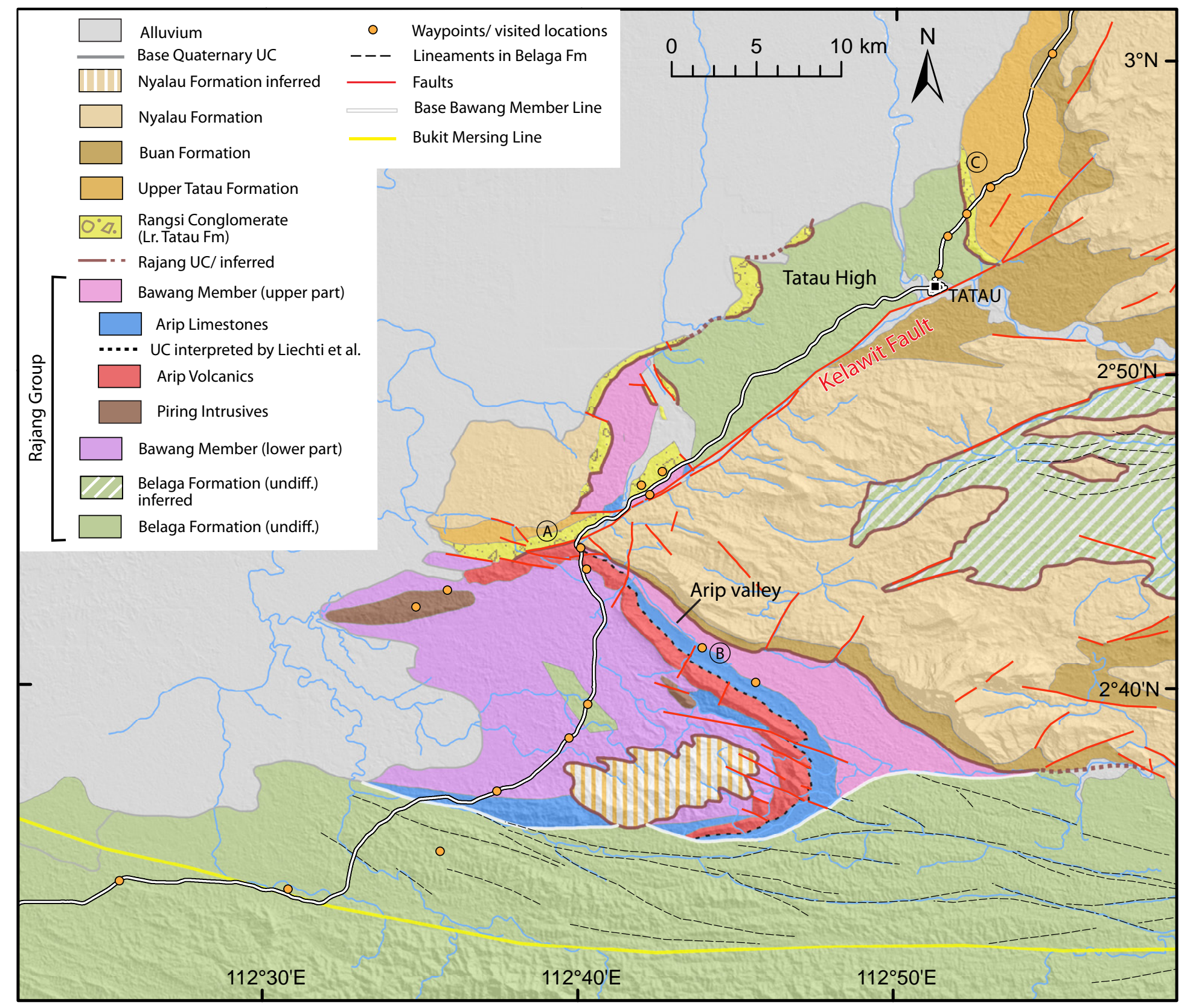

Fig. 1 
(A)

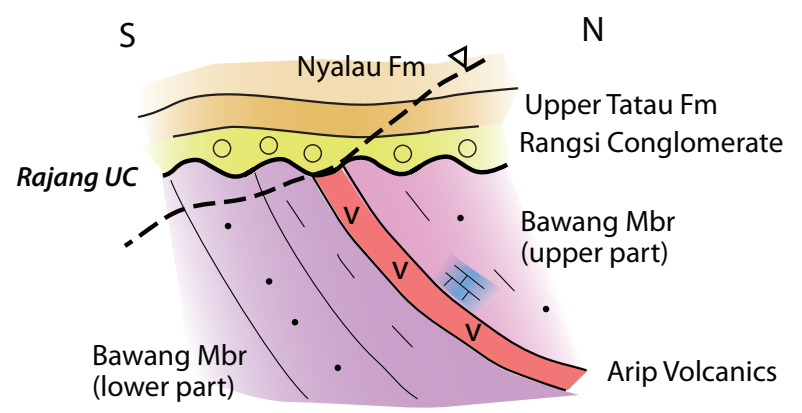

(C)

SW

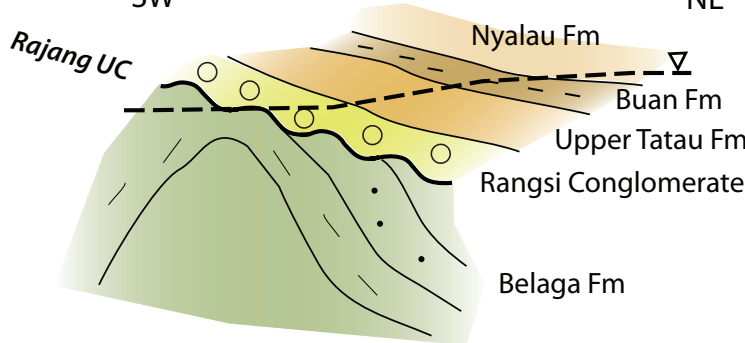

(B)

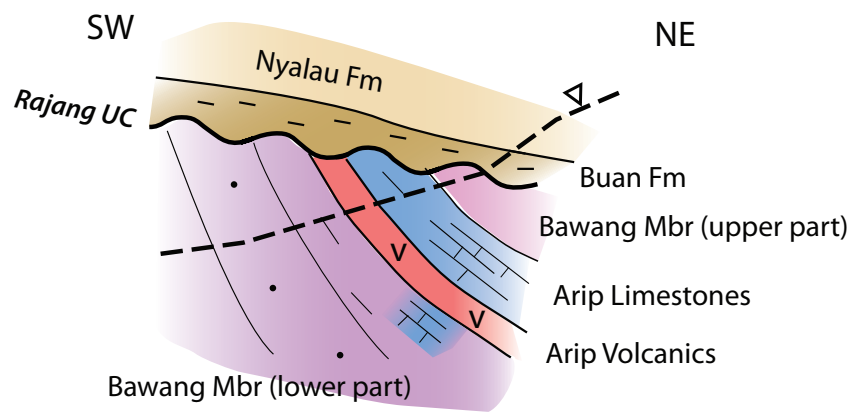

_- $\nabla_{\text {_ }}$ topographic profile

Mbr - Member

Fm - Formation

UC - Unconformity

Fig. 2 

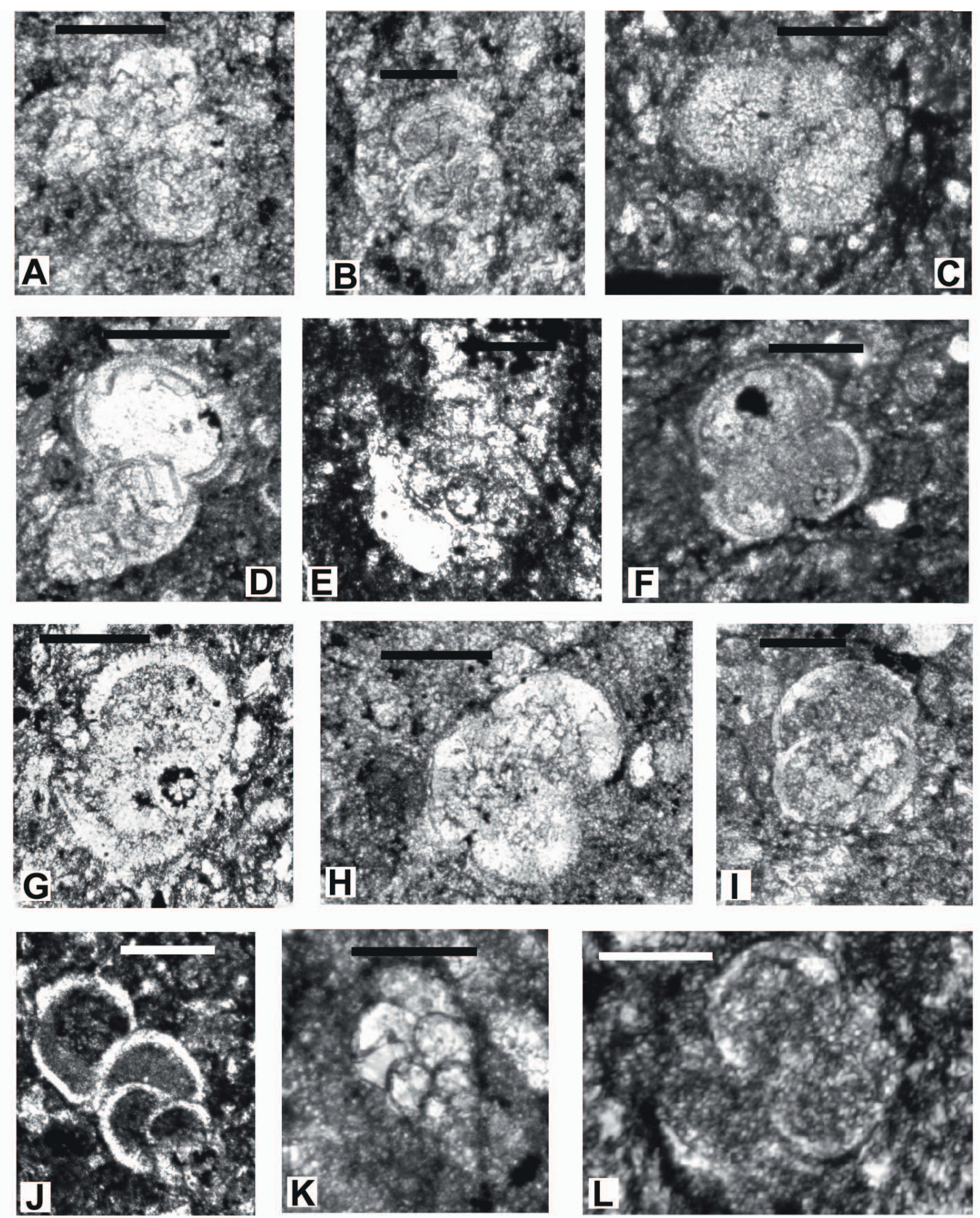

Fig. 3 